\title{
Time Management As A Means Of Achievement Of Program On Time Graduation In The Program Doctoral Universitas Negeri Semarang
}

\author{
Soegiyanto $^{1}$, Ipang Setiawan ${ }^{2}$ \\ \{Soegiyanto.ks@mail.unnes.ac.id ${ }^{1}$ \} \\ Sport Education Study Program, Universitas Negeri Semarang, Indonesia ${ }^{1,2}$
}

\begin{abstract}
Time Management is a new alternative that can be used to facilitate students in making graduation plans in undergraduate programs to doctoral. Through time management is expected to overcome the problem of graduation delays, because with this program can make students determine the priority and which should be abandoned, so that students can focus more on the task that should be resolved. The purpose of this research is to know the process of time management program as a means of achieving on time graduation in the doctoral program of Universitas Negeri Semarang. This research is a qualitative study, 1) conducted on a condition that is natural and direct to the data source and researchers are key instruments, 2) be a qualitative descriptive of aggregated data-shaped words or images, 3) more emphasis on Process of product 4) performs inductive data analysis, 5) More emphasizing the reversed meanings observed.
\end{abstract}

Keywords: time management, student, on time Graduation

\section{Introduction}

Students in sports education are sometimes experiencing difficulties in completing graduation conditions. Mujiah (2012) said the common problem is the lack of time management by students, so that many students are postponing in terms of completion of the final assignment. The difficulty in finding literature study also became a factor. The difficulties eventually caused the lazy student to complete the final assignment.

Time Management is a new alternative that can be used to facilitate students in making plans to graduate in the graduate program to the doctoral. Through time management is expected to overcome the problem of graduation delays. Because at this program it is able to make students sort out which ones are priority and which ones should be ruled out or abandoned. So that students can focus more on the task to be resolved.

Therefore, researchers feel the need to do some research on time management as a means of achievement of graduation On time program in the post-graduate doctoral program of Universitas Negeri Semarang.

Based on the background of the problem that has been revealed above, the problems that will be discussed in this research are:

How is the program of time management as a means of achieving an On Time management program in the post-graduate doctoral program of Universitas Negeri Semarang?. Based on the phenomenon of the above problems, the objectives of this research are: knowing the process of time management as a means of achievement of On time Management program in the post-graduate doctoral program of Universitas Negeri Semarang. 


\section{Theory}

Time Management is a new alternative that can be used to facilitate students in making graduation plans. Time Management becomes one of the important skills that everyone must have since it has become one of the keys in achieving success. Antonius Atosokhi Gea (2014:778) stated that Time Management is the act and process of planning a conscious control over a certain amount of time to be used for a particular activity, particularly to improve effectiveness, efficiency, and Productivity.

Time Management requires a number of skills, tools, and techniques used to manage the time to complete a project or task within a predetermined period of time. In this case because time is something very important and can not come back again. Because the time is seen as one of the main resources to achieve a success or mortgage. Therefore, through a Time Management program is expected to trigger the spirit and motivation of students to immediately complete the final task in order to obtain a diploma, Bachelor, magister to doctoral degree at the University.

Singh \& Jain (2013) stated that Time Management is an activity or process of logging and the implementation of conscious surveillance over a certain amount of time used for special activities, especially for improving effectiveness, efficiency, and productivity. Every student needs to learn and practice to save the time they have in order not to be wasted and be able to use it effectively and worthless. In Time Management A student can sort out which work should be completed first, where the work is a priority and which activities should be abandoned.

Time Management is directly related to performance and satisfaction issues, but it can reduce anxiety and worry. This is because time management helps students to learn how to manage the time well, which will certainly help to feel more relaxed, focused, and able to control the situation. A good time in the work done means to do high-quality work, not particularly high in terms of quantity Antonius Atosokhi Gea (2014:780).

The program that is done in order to achieve on time graduation can be an education in the following:

- Contract signatures. Contract signatures include agreements and approvals that students will execute approved and signed agreements. In this case, students will feel the responsibility to carry out the contents of the agreement. The agreement contains dates or schedules governing the completion of the final assignment to obtain approval. Starting from when they had to submit a title, then when they completed chapter 1 to completion, when their date completed the guidance, when the maximum they registered the trial, and when the maximum they completed the revision.

- Monitoring of guidance lecturer. The guidance lecturer is tasked to monitor student schedules and evaluate each month on students. This aims to make students feel aware by the advisers, so as to raise the spirit of students in working on the final task to obtain a degree in accordance with the education program.

- Warning. Lecturers should provide a perigement to students when conducting a time management program is not properly performed or violated. It aims to make the students strive to implement a time management program with the most.

- Punishment. Penalties are given to students who have violated or did not perform the agreement or repeatedly violated after being given a perigtion. This sentence aims to 
make students deterrent and other students do not underestimate the time management program.

Effective time management does not come for a while, there needs to be a time setting that has been made, it should be done well.

Passing on time is a hope for every student. For some students pass on time need sacrifices. Here are the factors that inhibit the completion of student studies according to the Factor analyst summary (Hisyam Ihsan and Ahmad Zaki, 2015:31).

- The first factor consists of health variables, intelligence, talents, parent and child relationships, relationships between family members, and curriculum.

- The second factor consists of the variables of readiness, interest, cultural background, relationship between lecturers and students.

- The third factor consists of family economic state variables, student relationships with other students, campus discipline, and organization.

\section{Method}

The method of research is a scientific way to obtain data and to have a specific purpose and usability (Sugiyono, 2015:3). A scientific study is essentially an attempt to determine, develop and test the truthfulness of a science. In an attempt to find and test the truth is done to accomplish a goal. In this study used qualitative research. It is qualitative because this research: 1) is conducted on a natural condition and directly to the data source and the researcher is a key instrument, 2) is a qualitative descriptive of data collected in the form of words or images, so as not to emphasize On the figure, 3) More emphasis on the process than the product or outcome, 4) conducting an inductive data analysis, 5) more emphasizing the reversed meaning observed (Sugiyono, 2015:21).

The research site was conducted at the Graduate School of Universitas Negeri Semarang. The objectives in this study were the management, executor, and graduate students of the State Universitas Negeri Semarang.

According to Suharsimi Arikunto (2010:149), research instruments are tools or facilities used by researchers in collecting data so that the work is more effective and results are better so that the research results to be easier in Processing. The research instruments used in this study are using complementary data documentation, observation, and interviews.

Therefore, the statements above the technique or way of collecting data in this study use the following instruments:

- Observation is also called observation, which includes observation activities of objects using the entire sensory appliance. In using observation method the most effective way is to complement it with the format and printing observation as an instrument (Suharsimi arikunto, 2010:228).

- Interview/interview, interview alone is a dialogue done by the interviewer to obtain information from the interview (Suharsimi Arikunto, 2010:155). Interviews are a fairly effective way the data will be obtained in full, less obvious or doubtful questions can be obtained right now (Nana Syaodih Sumadinata, 2011:84).

- Documentation, from the origin of the Word document, which means written goods. Bogdan and Biklen stating the photos produce a reasonably valuable and often used descriptive data to study subjective facets and the results are often analyzed inductive, there are two categories of photographs that can be utilized in research Qualitative is the 
photo produced by the person and the photo produced by the researcher himself (Moleong, L.J., 2010:160).

All three data collection techniques used have their own instruments. The above data collection instruments will be strengthened by the interviews of some of the interviewees who can be trusted as additional information.

The validity of data is very important in qualitative research, because it is a guarantee of confidence in the resolution of the problems studied. The legality technique check is based on a number of certain criteria. There are four criteria used to examine the validity of data, i.e. degrees of trust (credibility), transferability, dependability, and Confirmability (Moleong, L.J., 2010:324).

- Degrees of trust (Credibility), Researchers use two techniques of data credibility checking, i.e. 1) improved persistence. Improving diligence means observing more carefully and continuously (Sugiyono, 2015:370). and 2) triangulation. Data triangulation is a data validity checking technique that utilizes something else (Moleong, L.J., 2010:330).

Transferability indicates the degree of accuracy to which the research results can be applied or used in other situations (Sugiyono, 2015:376).

- Dependability in qualitative research was conducted by conducting audits of the entire research process (Sugiyono, 2015:377).

- Confirmability is called also a research objectivity. Research is said to be objective when the research results have been agreed many people. This test is almost identical to the dependability test, which is to test the results of the research associated with the process done before the results of the study were obtained.

Research data analysis techniques are one of the very important steps in the research process because this is where the research results will be visible. Data collection generates written records, interview results, documentation, and audio about conversations containing plural data fragments that are later analysed. Technical data analysis includes data reduction and data presentation.

The conclusion expressed in the early stages is supported by valid and consistent evidence as researchers return to the field collecting data, hence the conclusion expressed as a credible conclusion (Sugiyono, 2015:345).

\section{Disscussion}

Time management is a self-regulation in using time effectively and efficiently by planning and being able to make priorities well. Time management is one of the internal factors for students to apply the principle of efficient learning.

Based on the research finding and validity test, it was found that scale result of selfregulated learning consisting of 52 items was 40 valid and 12 invalid. The time management scale consisting of 44 items has 34 valid items and 10 invalid items.

The reliability test of the self-regulated learning scale and the time management scale use statistical techniques, namely the Cronbach Alpha formula. The result of self-regulated learning scale was obtained a coefficient of 0.954 . The result of time management scale was obtained a coefficient of 0.932 . Both scales were declared reliable in high category. The method of data analysis in this study used product moment correlation statistics from Karl Pearson. 
The result of the study showed that self-regulated learning and time management had by postgraduate students in UNNES postgraduate program is in high criteria. The result of correlation coefficient analysis ( $r)$ amounted to 0.925 with $p=0,000(p<0.01)$ which means that it has a positive value indicating a positive relationship classified as significant between variables $\mathrm{X}$ and $\mathrm{Y}$ (Arikunto 2006: 276). It shows that students have high motivation to complete their thesis. Motivation in self-regulated learning reveals about activities that are full of goals in starting, organizing or adding willingness to start, preparing for the next task or completing certain activities according to the objectives.

The most fundamental factors of self-regulated learning are the desire to achieve goals, awareness of self-respect, desire to try, commitment, time management, awareness of metacognitive, efficient use of strategies. Students who have high self-regulated learning in completing their thesis can be seen through the following characteristics: not being easily discouraged, being diligent to books or references, being diligent to do guidance, being tenacious, and being diligent to work on thesis and dissertation.

The results of data analysis showed that in general, time management falls into the medium and high category. It shows that the time management of students is included into good category. Students composing a thesis and dissertation are able to formulate the objectives of each activity carried out both short and long term goals. The objectives of students writing thesis are very diverse. They are to get a degree, to quickly get a decent job, and to have people's impression on their high education.

The results of the study generally indicate that students belong to high criteria. This is not in accordance with the initial phenomena of this study in which student time management and self-regulated learning are poor. The inconsistency of the results and initial phenomena might be caused by a long time span between preliminary studies which also influences the results of this study. The similarities in the indicators of self-regulated learning and time management scales determine the goals and schedules. Students tend to choose the right answer and at the time the research is going, students are diligent to do guidance to complete their thesis and dissertation.

The number of activities carried out by students requires them to have time management skills. Most students still do not have good time management. This lack of time management can result in learning outcomes that are not in line with expectations. To have good time management skills, students must pay attention to aspects that must be done and avoided.

The effort that needs to be done by students to have good time management is to avoid wasting time. Habits such as checking cellphones, accessing social media are becoming habits that do not seem it is wasting time a lot. Students must also have an assertive attitude so they can focus on activities that lead to goals. Playing activities that are sometimes unplanned can spend more time. Time management carried out by students can influence the learning outcomes obtained. Efficient time management can produce good learning achievements so they can graduate on time.

\section{Conclusion}

There are differences between the results of the study with the initial study. The results of the study showed that self-regulated learning and management time are included in the high criteria while the preliminary study showed that students in 2017 and 2018 are in the low category. 
There is a significant relationship between time management and self-regulated learning in students of Psychology and Counseling Guidance, Faculty of Education, Universitas Negeri Semarang. 


\section{References}

[1] Arikunto, S. 2010. Prosedur Penelitian Suatu Pendekatan Praktik Revisi VI. Jakarta: PT Asdi Mahasatya.

[2] Gea, Antonius A. 2014. TIME Management: Menggunakan Waktu secara Efektif dan Efisien. Jurnal Binus. 5(2): 777-783.

[3] Ihsan, Hisyam \& Zaki, Ahmad. 2015. Analisis Faktor-faktor yang Menghambat Penyelesaian Studi Mahasiswa FMIPA UNM. Indonesian Journal of Fundamental Sciences. 1(1): 25-33.

[4] Moleong, L. J. 2010. Metodologi Peneltian Kualitatif. Bandung: Remaja Rosda Karya

[5] Mujiyah. (2012). Kendala Mahasiswa FIP Dalam Menulis Tugas Akhir Skripsi. Yogyakarta: Lembaga Penelitian. LaporanPenelitian.

[6] Sugiyono. 2015. Metode Penelitian Kombinasi (Mixed Methods). Bandung: Alfabeta

[7] Sukmadinata, Nana Syaodih. 2013. Metode Penelitian Pendidikan. Bandung : PT Remaja Rosdakarya. 